\title{
Cutaneous B-cell lymphomas: 2019 update on diagnosis, risk stratification, and management
}

\author{
Ryan A. Wilcox
}

Division of Hematology/Oncology, University of Michigan, Rogel Cancer Center, Ann Arbor, Michigan

\section{Correspondence}

Ryan Wilcox, Division of Hematology/

Oncology, University of Michigan, Rogel

Cancer Center, 1500 E. Medical Center Drive,

Room 4310 CC, Ann Arbor, Ml 48109-5948.

Email: rywilcox@med.umich.edu

Funding information

Leukemia and Lymphoma Society; National Institutes of Health, Grant/Award Number: K08CA172215
Disease overview: Approximately one-fourth of cutaneous lymphomas are B-cell derived and are generally classified into three distinct subgroups: primary cutaneous follicle center lymphoma (PCFCL), primary cutaneous marginal zone lymphoma (PCMZL), and primary cutaneous diffuse large B-cell lymphoma, leg type (PCDLBCL, LT).

Diagnosis: Diagnosis and disease classification are based on histologic review and immunohistochemical staining of an appropriate skin biopsy. Pathologic review and an appropriate staging evaluation are necessary to distinguish primary cutaneous B-cell lymphomas from systemic Bcell lymphomas with secondary skin involvement.

Risk stratification: Disease histology remains the most important prognostic determinant. Both PCFCL and PCMZL are indolent lymphomas that infrequently disseminate to extracutaneous sites and are associated with 5 -year survival rates that exceed $95 \%$. In contrast, PCDLBCL, LT is an aggressive lymphoma with an inferior prognosis.

Risk-adapted therapy: PCFCL and PCMZL patients with solitary or relatively few skin lesions may be affectively managed with local radiation therapy. While single-agent rituximab may be employed for patients with more widespread skin involvement, multiagent chemotherapy is rarely appropriate. In contrast, management of patients with $P C D L B C L$, $L T$ is comparable to the management of patients with systemic DLBCL.

\section{1 | DISEASE OVERVIEW}

Primary cutaneous lymphomas are a heterogeneous group of extranodal non-Hodgkin lymphomas, approximately $25 \%$ of which are B-cell derived and are classified into three major entities in the 2008 World Health Organization-European Organization for Research and Treatment of Cancer (EORTC) joint classification: primary cutaneous follicle center lymphoma (PCFCL), primary cutaneous diffuse large B-cell lymphoma, leg type (PCDLBCL, $L T$ ), and primary cutaneous marginal zone lymphoma (PCMZL). ${ }^{1}$ The incidence of cutaneous B-cell lymphomas (CBCLs) has been increasing and is currently $\approx 4$ per million persons, based on Surveillance, Epidemiology, and End Results registry data, with the highest incidence rates being reported among males, nonHispanic whites, and adults over the age of 50 years. ${ }^{2,3}$

\section{DIAGNOSIS}

Diagnosis and classification of a CBCL requires an excisional or punch biopsy for careful morphologic and immunohistochemical analysis, and an appropriate staging evaluation to exclude systemic disease. ${ }^{4}$ The use of appropriate immunohistochemical stains (eg, CD5, cyclin D1) may also aid in distinguishing $C B C L$ from secondary skin involvement by a systemic lymphoma.

\subsection{Primary cutaneous follicle center lymphoma}

PCFCLs are commonly solitary plaques or tumors involving the trunk, particularly the head or scalp. While grouped lesions may be observed, multifocal disease is less common. Histologically, PCFCLs are characterized by a follicular, diffuse, or mixed growth pattern comprised of large centrocytes derived from germinal-center $B$ cells. ${ }^{1,5,6}$ In contrast to systemic follicular lymphomas, the majority of PCFCLs do not harbor the $\mathrm{t}(14 ; 18)$ translocation involving the bcl2 locus, and do not strongly express bcl- 2 by immunohistochemistry, although weak expression may be observed in a minority of cases. ${ }^{7-9}$ These CBCLs express bcl-6, variably express CD10, and are MUM$1 /$ IRF-4 negative, consistent with their origin from germinal-center $B$ cells. 


\subsection{Primary cutaneous diffuse large B-cell lymphoma, leg type}

In contrast to PCFCL, which is an indolent $\mathrm{CBCL}$ largely involving the head and trunk commonly affecting middle-aged adults, PCDLBCL, LT commonly affects elderly females and presents with rapidly progressive tumors involving the lower legs. ${ }^{10,11}$ Approximately $10 \%$ of cases may involve other cutaneous sites apart from the lower legs, and extracutaneous dissemination is common. ${ }^{11}$ These lymphomas are characterized by diffuse sheets of centroblasts and immunoblasts that spare the epidermis, but frequently extend deep into the dermis and subcutaneous tissue. In contrast to PCFCL, lymphoma cells highly express bcl-2, likely due to gene amplification, ${ }^{12,13}$ as $t(14 ; 18)$ is not observed in PCDLBCL, LT. Dual expression of both bcl-2 and c-myc is common, and is associated with inferior overall survival compared with the minority of PCDLBCL, LT that do not express c-myc. ${ }^{13} \mathrm{C}$ myc translocations (and "double hits") are rare among PCDLBCL, LT. ${ }^{13}$ Most cases are MUM-1/IRF- 4 and bcl- 6 positive, CD10 negative, and have a gene expression profile resembling activated $B$ cells. ${ }^{6}$ Perhaps not surprisingly, the genetic landscape observed in PCDLBCL, LT is similar to that observed in activated B-cell-type diffuse large B-cell lymphoma ( $\mathrm{ABC}-\mathrm{DLBCL}$ ), with NF-kB-activating mutations being observed in CD79B, CARD11, and MYD88. ${ }^{14-17}$ Of these, somatic MYD88 L265P mutations appear most common with a prevalence rate of $\approx 75 \% .{ }^{13,15-17}$ Despite the use of somatically hypermutated immunoglobulin heavy-chain variable (IGHV) regions, Staphylococcal superantigen binding sites within the IGHV are preserved, thus implicating superantigen-dependent B-cell receptor signaling in disease pathogenesis. ${ }^{18}$

\section{3 | Primary cutaneous marginal zone lymphoma}

Patients with PCMZL frequently present with multifocal patches, plaques or nodules involving the trunk and arms. While an association with Borrelia burgdorferi has been observed in Europe, a similar association has not been observed in cases from the United States. ${ }^{19-22}$ PCMZLs are composed of a mixed infiltrate of small, marginal zone B cells, lymphoplasmacytic cells, plasma cells, and reactive T cells. Marginal zone B cells characteristically express bcl-2, but lack bcl-6 or CD10 expression.

\section{3 | RISK STRATIFICATION}

The International Society for Cutaneous Lymphomas (ISCL) and EORTC recently proposed staging recommendations for cutaneous lymphomas other than mycosis fungoides and Sezary syndrome. ${ }^{4}$ Staging should include a history, physical examination, appropriate laboratory studies (including lactate dehydrogenase), and imaging (either CT, PET, or increasingly PET/CT) of the chest, abdomen, pelvis, and neck (in cases with involvement of the head or neck). A bone marrow biopsy and aspirate should be performed in cases of PCDLBCL, LT. The joint ISCL/EORTC does not endorse routine bone marrow examination in cases of PCFCL or PCMZL, although approximately $10 \%$ of patients with PCFCL have bone marrow involvement. ${ }^{23}$ Bone marrow involvement was associated with significantly inferior disease-specific survival. While the TNM staging classification describes the extent of disease, staging in $\mathrm{CBCL}$ is of limited prognostic value, as the disease histology is the major determinant in risk stratification. This is highlighted by a population-based study which identified histology and the site of skin involvement as important prognostic factors. ${ }^{24}$ In contrast, the International Extranodal Lymphoma Study Group identified three independent prognostic factors (ie, elevated LDH, >2 skin lesions, and nodular lesions) among patients with PCFCL and PCMZL. These factors were combined to form the cutaneous lymphoma international prognostic index (CLIPI). The absence of any adverse prognostic factor was associated with a 5 -year progression-free survival of $91 \%$. In contrast, the presence of two or three adverse prognostic factors was associated with a 5-year progression-free survival of $48 \%$. As the vast majority of relapses were confined to the skin, the CLIPI was unable to risk-stratify patients by overall survival. The presence of multiple skin lesions was associated with inferior disease-free survival in a European series, ${ }^{25}$ but was not associated with disease-free survival in a large North American series. ${ }^{26}$ The most important factor for risk stratification among the $\mathrm{CBCLs}$ remains the histologic classification. Indolent $\mathrm{CBCL}$ (PCFCL and PCMZL) are associated with 5-year disease-specific survival $\geq 95 \%$. ${ }^{1,26}$ Differences in growth pattern, the density of centroblasts, and cytogenetic findings do not appear to provide meaningful prognostic information. $\mathrm{Bcl}-2$ expression among PCFCL with a diffuse large B-cell histology may be a notable exception. ${ }^{27}$ In contrast, PCDLBCL, LT is associated with a 5 -year disease-specific survival of approximately $50 \%$, and dual bcl-2 and c-myc expression is associated with inferior survival. ${ }^{1,13,15,28}$ The presence of a somatic MYD88 ${ }^{\mathrm{L} 265 \mathrm{P}}$ mutation is also associated with inferior disease-specific and overall survival. ${ }^{15}$ In contrast to patients presenting with only a single tumor, involvement of multiple sites, on one or both legs, is associated with a significantly inferior disease-specific survival. ${ }^{29}$

\section{4 | TREATMENT}

As no randomized controlled trials are available, treatment recommendations for $\mathrm{CBCL}$ are largely based on small retrospective studies and institutional experience. The EORTC and ISCL have published consensus treatment recommendations that are consistent with $\mathrm{NCCN}$ guidelines. $^{30}$ In most cases, optimal patient management requires a multidisciplinary approach, including dermatology, medical oncology, and radiation oncology.

\section{1 | Primary cutaneous follicle center lymphoma}

For patients with solitary lesions, low-dose radiation therapy is safe and highly affective, with a complete remission rate approaching $100 \%$. Radiation does not appear inferior to multiagent chemotherapy among patients with multiple lesions that can be included in multiple radiation fields. ${ }^{31}$ In a large North American series, the rate of local control for indolent $\mathrm{CBCL}$ with radiation alone was $98 \%{ }^{26}$ In the same series, a local recurrence requiring radiation therapy was observed in $25 \%$ of patients who had undergone surgical excision alone. Reserving radiation until disease recurrence did not appear to 
compromise disease-specific or overall survival. ${ }^{26}$ Therefore, complete excision alone, deferring radiation until disease recurrence, is also reasonable. Intralesional (eg, corticosteroids or rituximab ${ }^{32}$ ) or topical therapies may also be considered. ${ }^{33,34}$ While radiation therapy is generally recommended for patients with a solitary lesion, radiation therapy, or observation (ie, "watch and wait") are reasonable options for those patients with multiple lesions. Patients with more extensive skin involvement are effectively managed with single-agent rituximab. ${ }^{30}$ Approximately one-third of patients may relapse following either radiation or single-agent rituximab, but relapses are usually confined to the skin and are approached in a manner similar to that described for the initial management of PCFCL.

\section{2 | Primary cutaneous marginal zone lymphoma}

Patients with PCMZL are approached in a manner analogous to that described in the initial management of PCFCL. Radiation therapy is associated with a similarly high response rate for patients with a single or few lesions. ${ }^{30}$ Those with more widespread skin involvement may be observed. Once symptomatic, culprit lesion may be irradiated (or surgically excised). As for PCFCL, single-agent rituximab may be utilized in patients with symptomatic, widespread skin lesions. An initial trial of antibiotics for those with B. burgdorferi-associated PCMZL has been recommended, ${ }^{35}$ but is less relevant for North American patients.

\section{3 | Primary cutaneous diffuse large B-cell lymphoma, leg type}

As previously noted, the natural history of PCDLBCL, LT more closely resembles that of systemic DLBCL. Therefore, $\mathrm{R}-\mathrm{CHOP}$ (with or without radiation therapy) is utilized in these patients. While few reports are available in the literature, the use of R-CHOP in these patients is associated with disease-free survival rates rivaling those reported for patients with high-risk systemic DLBCL. ${ }^{10,11,26,30}$ Most patients present with disease confined to the leg(s) and are managed like patients with limited stage systemic DLBCL with R-CHOP and involved field radiation therapy. The management of relapsed disease is comparable to that for relapsed systemic $A B C-D L B C L$ (eg, lenalidomide ${ }^{36}$ and ibrutinib $\left.{ }^{37}\right)$. In a small phase II study $(n=19)$, the 6-month overall response rate with single-agent lenalidomide in relapsed/refractory PCDLBCL, LT was $26 \%$, but was significantly higher in patients without the MYD88 ${ }^{\mathrm{L} 265 \mathrm{P}}$ mutation. ${ }^{38}$

\section{ACKNOWLEDGMENT}

This work was supported in part by the National Institutes of Health (K08CA172215) and the Leukemia and Lymphoma Society Translational Research Program.

\section{CONFLICT OF INTEREST}

Nothing to report.

\section{ORCID}

Ryan A. Wilcox (D) http://orcid.org/0000-0002-6420-0760

\section{REFERENCES}

1. Willemze R, Jaffe ES, Burg G, et al. WHO-EORTC classification for cutaneous lymphomas. Blood. 2005;105:3768-3785.

2. Bradford PT, Devesa SS, Anderson WF, Toro JR. Cutaneous lymphoma incidence patterns in the United States: a population-based study of 3884 cases. Blood. 2009;113:5064-5073.

3. Korgavkar K, Weinstock MA. Changing incidence trends of cutaneous B-cell lymphoma. J Invest Dermatol. 2014;134:840-842.

4. Kim YH, Willemze R, Pimpinelli N, et al. TNM classification system for primary cutaneous lymphomas other than mycosis fungoides and Sezary syndrome: a proposal of the International Society for Cutaneous Lymphomas (ISCL) and the cutaneous lymphoma task force of the European Organization of Research and Treatment of cancer (EORTC). Blood. 2007;110:479-484.

5. Gellrich S, Rutz S, Golembowski S, et al. Primary cutaneous follicle center cell lymphomas and large B cell lymphomas of the leg descend from germinal center cells. A single cell polymerase chain reaction analysis. J Invest Dermatol. 2001;117:1512-1520.

6. Hoefnagel JJ, Dijkman R, Basso K, et al. Distinct types of primary cutaneous large B-cell lymphoma identified by gene expression profiling. Blood. 2005;105:3671-3678.

7. Cerroni L, Kerl H. Immunoreactivity for bcl-2 protein in cutaneous lymphomas and lymphoid hyperplasias. J Cutan Pathol. 1995;22: 476-478.

8. Cerroni L, Volkenandt M, Rieger E, Soyer HP, Kerl H. bcl-2 protein expression and correlation with the interchromosomal 14;18 translocation in cutaneous lymphomas and pseudolymphomas. J Invest Dermatol. 1994;102:231-235.

9. Cerroni L, Arzberger E, Putz B, et al. Primary cutaneous follicle center cell lymphoma with follicular growth pattern. Blood. 2000;95: 3922-3928.

10. Grange F, Beylot-Barry M, Courville $P$, et al. Primary cutaneous diffuse large B-cell lymphoma, leg type: clinicopathologic features and prognostic analysis in 60 cases. Arch Dermatol. 2007;143:1144-1150.

11. Senff NJ, Hoefnagel JJ, Jansen PM, et al. Reclassification of 300 primary cutaneous B-cell lymphomas according to the new WHO-EORTC classification for cutaneous lymphomas: comparison with previous classifications and identification of prognostic markers. J Clin Oncol. 2007;25:1581-1587.

12. Mao X, Lillington D, Child F, Russell-Jones R, Young B, Whittaker S. Comparative genomic hybridization analysis of primary cutaneous B-cell lymphomas: identification of common genomic alterations in disease pathogenesis. Genes Chromosomes Cancer. 2002;35:144-155.

13. Menguy S, Frison E, Prochazkova-Carlotti M, et al. Double-hit or dual expression of MYC and BCL2 in primary cutaneous large B-cell lymphomas. Mod Pathol. 2018. (in press)

14. Koens L, Zoutman WH, Ngarmlertsirichai $P$, et al. Nuclear factor-kappaB pathway-activating gene aberrancies in primary cutaneous large B-cell lymphoma, leg type. J Invest Dermatol. 2014;134: 290-292.

15. Pham-Ledard A, Beylot-Barry M, Barbe C, et al. High frequency and clinical prognostic value of MYD88 L265P mutation in primary cutaneous diffuse large B-cell lymphoma, leg-type. JAMA Dermatol. 2014; 150:1173-1179.

16. Menguy S, Gros A, Pham-Ledard A, et al. MYD88 somatic mutation is a diagnostic criterion in primary cutaneous large B-cell lymphoma. J Invest Dermatol. 2016;136:1741-1744.

17. Mareschal S, Pham-Ledard A, Viailly PJ, et al. Identification of somatic mutations in primary cutaneous diffuse large B-cell lymphoma, leg type by massive parallel sequencing. J Invest Dermatol. 2017;137: 1984-1994.

18. Pham-Ledard A, Prochazkova-Carlotti M, Deveza M, et al. Molecular analysis of immunoglobulin variable genes supports a germinal center experienced normal counterpart in primary cutaneous diffuse large B-cell lymphoma, leg-type. J Dermatol Sci. 2017;88:238-246.

19. Cerroni L, Zochling N, Putz B, Kerl H. Infection by Borrelia burgdorferi and cutaneous B-cell lymphoma. J Cutan Pathol. 1997;24:457-461.

20. Goodlad JR, Davidson MM, Hollowood K, Batstone P, Ho-Yen DO. Borrelia burgdorferi-associated cutaneous marginal zone lymphoma: a clinicopathological study of two cases illustrating the temporal 
progression of B. burgdorferi-associated B-cell proliferation in the skin. Histopathology. 2000;37:501-508.

21. Goodlad JR, Davidson MM, Hollowood K, et al. Primary cutaneous B-cell lymphoma and Borrelia burgdorferi infection in patients from the Highlands of Scotland. Am J Surg Pathol. 2000;24:1279-1285.

22. Wood GS, Kamath NV, Guitart J, et al. Absence of Borrelia burgdorferi DNA in cutaneous B-cell lymphomas from the United States. J Cutan Pathol. 2001;28:502-507.

23. Senff NJ, Kluin-Nelemans HC, Willemze R. Results of bone marrow examination in 275 patients with histological features that suggest an indolent type of cutaneous B-cell lymphoma. Br J Haematol. 2008; 142:52-56.

24. Smith BD, Smith GL, Cooper DL, Wilson LD. The cutaneous B-cell lymphoma prognostic index: a novel prognostic index derived from a population-based registry. J Clin Oncol. 2005;23:3390-3395.

25. Zinzani PL, Quaglino P, Pimpinelli N, et al. Prognostic factors in primary cutaneous B-cell lymphoma: the Italian Study Group for Cutaneous Lymphomas. J Clin Oncol. 2006;24:1376-1382.

26. Hamilton SN, Wai ES, Tan K, Alexander C, Gascoyne RD, Connors JM. Treatment and outcomes in patients with primary cutaneous B-cell lymphoma: the BC Cancer Agency experience. Int J Radiat Oncol Biol Phys. 2013;87:719-725.

27. Grange F, Petrella T, Beylot-Barry M, et al. Bcl-2 protein expression is the strongest independent prognostic factor of survival in primary cutaneous large B-cell lymphomas. Blood. 2004;103:3662-3668.

28. Hallermann C, Kaune KM, Gesk S, et al. Molecular cytogenetic analysis of chromosomal breakpoints in the IGH, MYC, BCL6, and MALT1 gene loci in primary cutaneous B-cell lymphomas. J Invest Dermatol. 2004;123:213-219.

29. Grange F, Bekkenk MW, Wechsler J, et al. Prognostic factors in primary cutaneous large B-cell lymphomas: a European multicenter study. J Clin Oncol. 2001;19:3602-3610.

30. Senff NJ, Noordijk EM, Kim YH, et al. European Organization for Research and Treatment of Cancer and International Society for Cutaneous Lymphoma consensus recommendations for the management of cutaneous B-cell lymphomas. Blood. 2008;112:1600-1609.
31. Bekkenk MW, Vermeer MH, Geerts ML, et al. Treatment of multifocal primary cutaneous B-cell lymphoma: a clinical follow-up study of 29 patients. J Clin Oncol. 1999;17:2471-2478.

32. Penate $\mathrm{Y}$, Hernandez-Machin B, Perez-Mendez LI, et al. Intralesional rituximab in the treatment of indolent primary cutaneous B-cell lymphomas: an epidemiological observational multicentre study. The Spanish Working Group on Cutaneous Lymphoma. Br J Dermatol. 2012;167:174-179.

33. Perry A, Vincent BJ, Parker SR. Intralesional corticosteroid therapy for primary cutaneous B-cell lymphoma. Br J Dermatol. 2010;163: 223-225.

34. Coors EA, Schuler G, Von Den Driesch P. Topical imiquimod as treatment for different kinds of cutaneous lymphoma. Eur J Dermatol. 2006;16:391-393.

35. Dreno B. Standard and new treatments in cutaneous B-cell lymphomas. J Cutan Pathol. 2006;33(Suppl 1):47-51.

36. Savini P, Lanzi A, Foschi FG, Marano G, Stefanini GF. Lenalidomide monotherapy in relapsed primary cutaneous diffuse large B cell lymphoma-leg type. Ann Hematol. 2014;93:333-334.

37. Gupta E, Accurso J, Sluzevich J, Menke DM, Tun HW. Excellent outcome of immunomodulation or Bruton's tyrosine kinase inhibition in highly refractory primary cutaneous diffuse large B-cell lymphoma, leg type. Rare Tumors. 2015;7:6067.

38. Beylot-Barry M, Mermin D, Maillard A, et al. A single-arm phase II trial of lenalidomide in relapsing or refractory primary cutaneous large B-cell lymphoma leg-type. J Invest Dermatol. 2018. (in press)

How to cite this article: Wilcox RA. Cutaneous B-cell lymphomas: 2019 update on diagnosis, risk stratification, and management. Am J Hematol. 2018;93:1427-1430. https://doi. org/10.1002/ajh.25224 